\title{
Challenging cow dung COVID therapies and bullshit state policies in India in 2021
}

\author{
Chandana Mathur ${ }^{1}$ D
}

Published online: 30 December 2021

(c) The Author(s), under exclusive licence to Springer Nature B.V. 2021

To recall the months of April and May 2021 as the second wave of COVID-19 crashed into India is to relive trauma-trauma inflicted by reports of the deadly shortages of medical oxygen, hospital beds and ventilators; desperate pleas on social media by relatives seeking these for their loved ones; long, snaking queues at cremation sites, some of which were hastily improvised in car parks and other open spaces; and unceasing flames from funeral pyres that burned night and day.

Alongside the unbearable suffering of the multitude was a dazzling display of what might (mistakenly) be regarded as irrationality on the part of India's Hindu right-wing leadership. Thus, the Kumbh Mela, the world's largest religious gathering, attracting Hindu pilgrims in their millions, was permitted to go ahead in the months of March and April, at the height of the COVID surge. Last held in 2010 and normally recurring every twelve years, the Kumbh Mela was held after only eleven years this time following astrological advice, and the Indian Railways ran special trains to ferry crowds of pilgrims to the holy sites (Sengupta 2021). The elections in the state of West Bengal were not postponed either and Prime Minister Modi himself addressed vast, jampacked rallies to get out the vote for the Bharatiya Janata Party (BJP). Far from being irrational, the state's decisions were based in the cold calculation that has characterised the Modi government's majoritarian political strategy, and its supposition, unfortunately often correct, that heightened religious fervour drives its electoral victories. These calculated state actions were arguably of a different order from the viral video clips of men smearing themselves with cow dung to fend off COVID infection in Gujarat, but such activities are part of the ecosystem that nourishes and is nourished by the Hindu Right, influential to the point that the Indian Medical Association was obliged to release a statement saying that this was useless from a therapeutic standpoint and indeed likely to have damaging health consequences (Sharma 2021b).

Given that Hindu majoritarian mobilisation since the late 1980s has frequently exploded into violence, some observers have tended to think of it as an unpredictable

Chandana Mathur

Chandana.Mathur@mu.ie

1 Department of Anthropology, National University of Ireland, Maynooth, Ireland 
and disruptive force that is threatening to business-as-usual. Others, such as economist Jayati Ghosh, have pointed out, however, that raging Hindu majoritarianism in the Modi era has been completely compatible with no-holds-barred capitalism (Ghosh 2020). Nonetheless, keeping Hindu Right supporters onboard has necessitated the continual broadcasting of good news regarding the state of the Indian economy. Ghosh details in this context the government's unprecedented attack on the credibility of independent bodies like the Central Statistical Organisation and the numerous efforts to suppress and falsify official economic data. Even if one regards the GDP and other economic indicators to be flawed forms of evidence, it is nonetheless alarming to see the historically independent national-level data of this kind being manipulated or concealed. Given the extensive fudging of the data collected by its own agencies, it is only to be expected that the Indian state will contest and discredit the data gathered by external agencies. The furore about alleged methodological shortcomings that arose in October 2021 when India was ranked 101st out of 116 countries on the Global Hunger Index is a case in point (https://www.globa lhungerindex.org/ranking.html). A key tactic of the Modi government is the release of carefully curated economic data intended to keep ordinary Indians in the dark about the material damage that the state has inflicted upon them in recent years.

During the pandemic, there has been an even greater imperative to project good news. This has led the Indian state to issue gross underestimates of deaths caused by COVID-19. According to Prabhat Jha (Principal Investigator of the Million Death Study, a decades-long, large-scale study of premature mortality in India), the work that he and his colleagues have done in recent months suggests that India's COVID death rate may be a staggering 7-8 times higher than the officially reported figure (Deshmukh et al. 2021). Other researchers-such as the economist Arvind Subramanian or the data journalist S Rukmini-have largely concurred with this estimate (Anand et al. 2021; Gupta et al. 2021), but there is also research that has preferred not to question government claims, such as the high-profile report on COVID deaths in the state of UP that was recently critiqued by Murad Banaji (Banaji 2021). This pressure to offer up good news has gone far beyond the undercounting of COVID deaths. Even an agency as prominent as the Indian Council of Medical Research was refusing to share granular data about the spread of the virus with other scientists and suppressing its own reports that did not fit in with the official narrative (Singh 2021). State control and surveillance do not end with key institutions or their research outputs; it may even extend to individual scholars. In the wake of the revelations about the Israeli spyware manufacturer NSO Group, it emerged that the Indian government had been snooping not just on the political opposition and journalists of independent views, but also the noted virologist Dr Gagandeep Kang. Her phone was one of those targeted and infected by Pegasus spyware (Sharma 2021a).

Speaking at the World Economic Forum in Davos in January 2021, Modi had prematurely declared India's victory over COVID 19, a fact that has been picked up by many commentators. His translated words have been replayed repeatedly: "In a country which is home to 18 percent of the world population, that country has saved humanity from a big disaster by containing corona effectively" (PIB 2021). But also at Davos, he boasted that "Even during Corona, India has accelerated the pace of structural reforms in almost every sector. These reforms are being 
supported through production-linked incentives" (PIB 2021). A key component of the reforms that he was speaking about were the three new farm laws passed in 2020 with the intention of intensifying the corporatisation of agriculture.

COVID-19 touched down in India in March 2020 at a time when anti-government protests, sparked by discriminatory new citizenship legislation passed in 2019, were sweeping the country. The chokehold of the Hindu Right on the Indian polity had been loosened for the first time in a very long time. And then, the calamitous unfolding of the pandemic swiftly scattered and destroyed this resistance, with the government using the cover of COVID-19 to silence its most vocal critics. However, the three new farm laws-with their potentially adverse consequences for the market prices of agricultural products and the bargaining power of farmers against powerful agribusinesses-galvanised India's farmers to launch a massive non-violent agitation in November 2020. Braving the pandemic, extremes of weather, police brutality, vilification by the government and media, and outright murderous violence, the farmers camped resolutely on the borders of Delhi from November 2020 to November 2021 to demand the repeal of these laws. They were supported by comrades from many of the alliances that had been formed during the Citizenship Amendment Act protests of 2019-2020 and even by Indian diaspora activists. The farmers prevailed in the end (even though over 700 protestors have lost their lives), and the laws have been repealed. As of this writing, the Samyukt Kisan Morcha, an umbrella organisation of over forty farmers' unions leading the protests, is ending the encampment at Delhi's borders but continuing to pursue its remaining demands, for a legally guaranteed minimum support price, for compensation for the families of farmers who died during the protests and so on. "This is not at all the end of the agrarian crisis" writes the journalist P Sainath. "It is the beginning of a new phase of the battle on the larger issues of that crisis" (Sainath 2021). It is also a sign that the pandemic cannot put an end to the surging people's movements in India.

\section{References}

Anand, Abhishek, Justin Sandefur, and Arvind Subramanian. 2021. Three new estimates of India's allcause excess mortality during the COVID-19 pandemic. CGD Working Paper 589. Washington, DC: Center for Global Development. https://cgdev. org/publication/three-new-estimates-indias-allcause-excess-mortality-during-covid-19-pandemic. Accessed 7 December 2021.

Banaji, Murad. 2021. Why the IIT Kanpur Report on UP's COVID-19 Crisis Was Dishonest. The Wire Science, 10 October 2021. https://science.thewire.in/health/iit-kanpur-report-manindra-agrawaluttar-pradesh-covid19-mortality/. Accessed 7 December 2021.

Deshmukh, Yashwant, Wilson Suraweera, Chinmay Tumbe, Aditi Bhowmick, Sankalp Sharma, Paul Novosad, Sze Hang Fu, Leslie Newcombe, Hellen Gelband, Patrick Brown, Prabhat Jha. 2021. Excess mortality in India from June 2020 to June 2021 during the COVID pandemic: death registration, health facility deaths, and survey data. medRxiv. https://www.medrxiv.org/content/https://doi. org/10.1101/2021.07.20.21260872v1. Accessed 7 December 2021.

Ghosh, Jayati. 2020. "Hindutva, Economic Neoliberalism and the Abuse of Economic Statistics in India", South Asia Multidisciplinary Academic Journal [Online], 24/25 I 2020. URL: http://journals.opene dition.org/samaj/6882; DOI: https://doi.org/10.4000/samaj.6882 
Gupta, Aashish, Dhanya Rajendran \& Rukmini S. 2021. India is undercounting Covid-19 deaths. Here's how to work around the problem. May 11, 2021. https://scroll.in/article/994619/india-is-undercount ing-covid-19-deaths-heres-how-to-work-around-the-problem. Accessed 7 December 2021.

PIB Delhi, Prime Minister's Office. 2021. English rendering of PM's address at the World Economic Forum's Davos Dialogue, posted on: 28 JAN 2021. Press Information Bureau (pib.gov.in) . Accessed 7 December 2021.

Sainath, P. 2021. Farmers win on many fronts, Media fails on all. 20 November 2021, People's Archive of Rural India, https://ruralindiaonline.org/en/articles/farmers-win-on-many-fronts-media-fails-on-all/. Accessed 7 December 2021.

Sengupta, Shuddhabrata. Leaders Listened to Astrologers, so Haridwar Mela Happened After 11 Years, Not 12. The Wire Science, April 23, 2021. https://science.thewire.in/health/leaders-listened-to-astro logers-so-haridwar-mela-happened-after-11-years-not-12/. Accessed 7 December 2021.

Sharma, Milan. 2021a. 'I do nothing controversial': Virologist Gagandeep Kang reacts after name appears in Pegasus list. India Today, July 20, 2021. https://www.indiatoday.in/india/story/virologistgagandeep-kang-reacts-pegasus-list-exclusive-1830192-2021-07-20. Accessed 7 December 2021.

Sharma, Shweta. 2021b. India's top medical association warns over 'health risks' of using cow dung as Covid treatment, Independent, 11 May 2021. https://www.independent.co.uk/asia/india/india-covidcow-dung-cure-b1845507.html. Accessed 7 December 2021.

Singh, Karan Deep. 2021. As India's lethal Covid wave neared, politics overrode science. New York Times, 14 September 2021. https://www.nytimes.com/2021/09/14/world/asia/india-modi-scienceicmr.html. Accessed 7 December 2021.

Publisher's Note Springer Nature remains neutral with regard to jurisdictional claims in published maps and institutional affiliations. 